\title{
Evolution of the 2015/16 El Niño and historical perspective since 1979
}

\author{
Yan $\mathrm{XUE}^{*} \&$ Arun KUMAR \\ Climate Prediction Center, National Centers for Environmental Prediction, National Weather Service, National Oceanic and Atmospheric \\ Administration, College Park, MD 20740, USA
}

Received July 21, 2016; accepted September 18, 2016; published online December 22, 2016

\begin{abstract}
The 2015/16 El Niño developed from weak warm conditions in late 2014 and NINO3.4 reached $3^{\circ} \mathrm{C}$ in November 2015. We describe the characteristics of the evolution of the 2015/16 El Niño using various data sets including SST, surface winds, outgoing longwave radiation and subsurface temperature from an ensemble operational ocean reanalyses, and place this event in the context of historical ENSO events since 1979. One salient feature about the 2015/16 El Niño was a large number of westerly wind bursts and downwelling oceanic Kelvin waves (DWKVs). Four DWKVs were observed in April-November 2015 that initiated and enhanced the eastern-central Pacific warming. Eastward zonal current anomalies associated with DWKVs advected the warm pool water eastward in spring/summer. An upwelling Kelvin wave (UWKV) emerged in early November 2015 leading to a rapid decline of the event. Another outstanding feature was that NINO4 reached a historical high $\left(1.7^{\circ} \mathrm{C}\right)$, which was $1^{\circ} \mathrm{C}\left(0.8^{\circ} \mathrm{C}\right)$ higher than that of the 1982/83 (1997/98) El Niño. Although NINO3 was comparable to that of the 1982/83 and 1997/98 El Niño, NINO1+2 was much weaker. Consistently, enhanced convection was displaced 20 degree westward, and the maximum D20 anomaly was about 1/3-1/2 of that in 1997 and 1982 near the west coast of South America.
\end{abstract}

Keywords ENSO, Sea surface temperature, Westerly wind bursts, Ocean Kelvin waves, Thermocline variability, Ocean reanalysis

Citation: Xue Y, Kumar A. 2017. Evolution of the 2015/16 El Niño and historical perspective since 1979. Science China Earth Sciences, 60: 1572-1588, doi: $10.1007 / \mathrm{s} 11430-016-0106-9$

\section{Introduction}

El Niño-Southern Oscillation (ENSO) is the dominant mode of interannual variability in the tropical Pacific and has far-reaching impacts on global climate (Trenberth et al., 1998). Since the upper ocean thermal structures provide the ocean memory for long-term predictability of ENSO (Zebiak, 1989), the in situ observations from the Tropical Atmospheric Ocean (TAO) array (McPhaden et al., 1998) and the Triangle Trans-Ocean Buoy Network (TRITON) array (Ando et al., 2005) have played a critical role in the development of ENSO theory, ENSO monitoring and prediction systems. The implementation of the TAO/TRITON

*Corresponding author (email: Yan.Xue@noaa.gov) array stimulated a rapid development of operational ocean reanalyses (ORAs), which provide ocean initializations for climate coupled models by combining in situ observations with model solutions via data assimilation methods (e.g. Behringer et al., 1998; Zhang et al., 2007; Yin et al., 2011; Xue et al., 2011; Balmaseda et al., 2013).

Although the primary purpose of operational ORAs is to provide ocean initializations for seasonal forecast models, operational ORAs are also routinely used for monitoring and forecasting ENSO in real-time. For example, at the Climate Prediction Center (CPC) of National Centers for Environmental Prediction (NCEP), the operational global ocean data assimilation system (GODAS, Behringer and Xue, 2004) has been used in monitoring the recent evolution of tropical $\mathrm{Pa}-$ cific temperature anomalies and the mixed layer heat bud- 
get associated with ENSO (Huang et al., 2010). In addition, a comprehensive web site based on the GODAS provides both climatology and anomaly for many variables for each month since 1979 (http://www.cpc.ncep.noaa.gov/products/GODAS/). This is a useful tool to examine ocean variability for both current and historical ENSO events.

The quality of operational ORAs depends critically on the data availability from the TAO/TRITON array. Recently, there was a rapid decline of the TAO array after summer 2012 and the data return rate from the TAO array decreased to $40 \%$ of its historical average (Figure 1a). This degradation of the TAO/TRITON array raised serious concerns about whether the quality of the operational ORAs was compromised due to the data loss. Following the TPOS 2020 workshop in Jan- uary 2014 (http://www.ioc-goos.org/tpos2020), a Real-time Ocean Reanalysis Intercomparison Project (http://www.cpc. ncep.noaa.gov/products/GODAS/multiora body.html) was established to monitor the consistency among the tropical Pacific temperature analyses across the operational ORAs in real time.

Thanks to the rapid response by the United States National Oceanic and Atmospheric Administration (NOAA), the TAO array was restored to a $90 \%$ data return rate in late 2014 (Figure 1). In addition, modified Argo floats (with less amount of surface drift) were deployed along the equatorial belt starting early 2014. The near $90 \%$ return rate of the TAO array in late 2014 had perfect timing and provided the data required for monitoring the development of the 2015/16 El Niño.
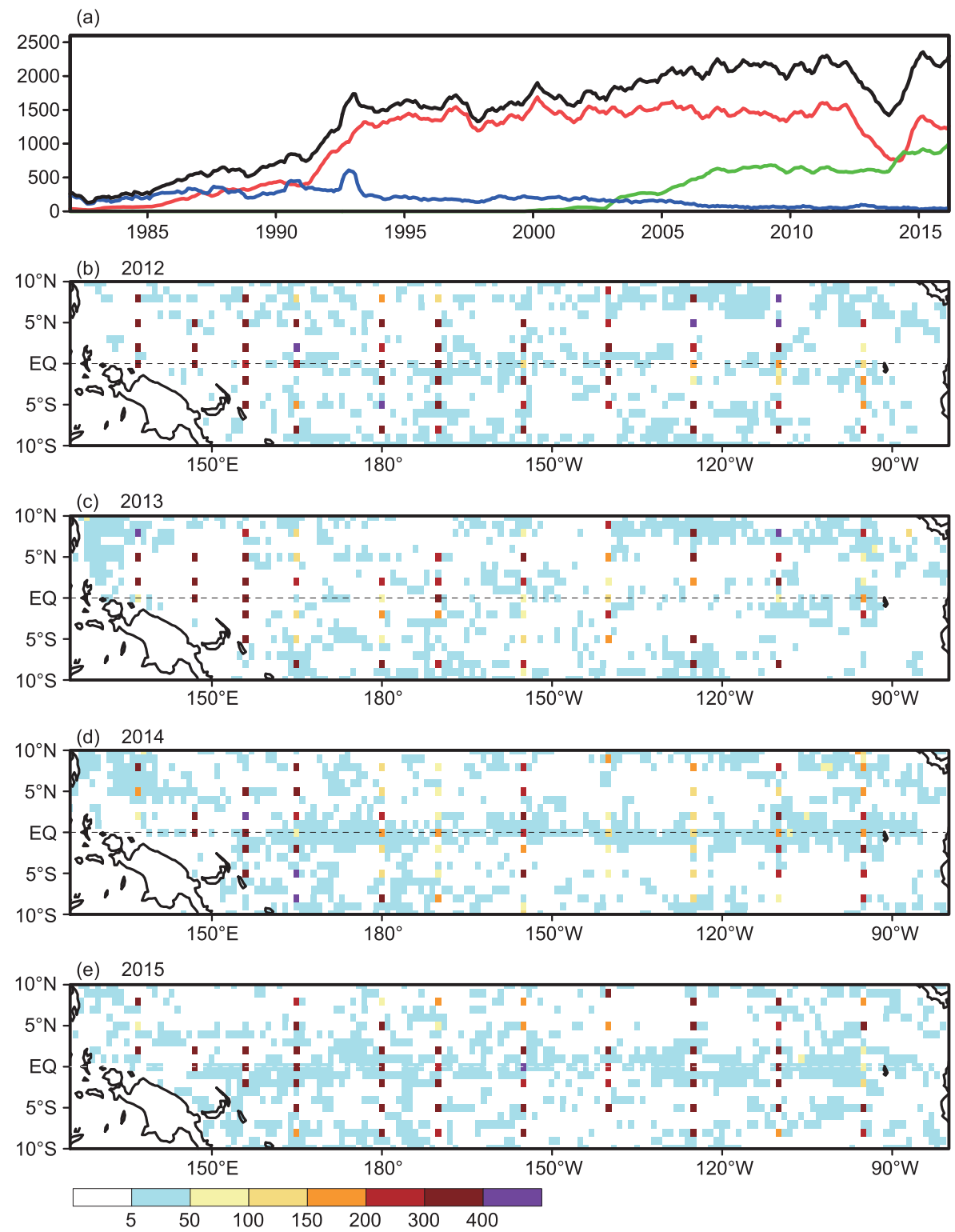

Figure 1 Time series of number of daily temperature profiles per month accumulated in the tropical Pacific within $8^{\circ} \mathrm{S}-8^{\circ} \mathrm{N}$ from TAO/TRITON (red line), Argo (green line), XBT (blue line) and TAO/TRITON/Argo/XBT together (black line) from January 1982 to March 2015 (a). Number of daily temperature profiles accumulated in 2012 (b), 2013 (c), 2014 (d) and 2015 (e). 
Due to the rich data from the TAO/TRITON array and Argo floats, the consistency among ensemble ORAs has been quite high, particularly along the equatorial Pacific (Figure 2 ) where the subsurface temperature anomalies provide the ocean memory for long-lead prediction skill of ENSO (Ji et al., 1998; Stockdale et al., 2011). In this paper, we used the ensemble mean temperature anomalies calculated from six ORAs to describe the evolution of 2015/16 El Niño. The ensemble mean approach helps reduce errors in individual ORA and provides a more robust estimate for temperature analysis. Our approach differs from that of McPhaden (1999) in which the TAO/TRITON data alone was used in describing the evolution of the 1997/98 El Niño.

The 2015/16 El Niño reached an amplitude that was similar to that of the 1982/83 and 1997/98 El Niño based on a SST product (https://www.climate.gov/news-features/blogs/enso/april-2016-el-ni\%C3\%B1ola-ni\%C3\%B1aupdate-what-goes- $\% \mathrm{E} 2 \% 80 \% \mathrm{~A} 6$ ). The paper aims to describe the characteristics of the evolution of the 2015/16 El Niño and also compares it with the 1982/83 and 1997/98 El Niño due to their similar amplitude.

\section{Data sets and methods}

\subsection{Subsurface temperature from ensemble operational ocean reanalyses}

Ocean reanalyses aim to provide an estimate of 3-dimensional structures of the ocean by combining model solutions (often referred as the first guess) with ocean observations using data assimilation methods. However, the time evolutions of the ocean represented by an ORA are sensitive to the temporal variations of the observing system, to the errors in the ocean model, to the specification of atmospheric fluxes and to the data assimilation techniques. Further, these features are often flow-dependent, and associated errors are not easy to estimate. A simple and a pragmatic way of estimating uncertainties in ORAs is an intercomparison of ORAs within the framework of an ensemble approach (Balmaseda et al., 2015).

In the ensemble approach, the signal in the ocean state is estimated as the ensemble mean (EM) defined by

$$
E M(t)=\frac{1}{N} \sum_{k=1}^{N} X_{k}(t)
$$

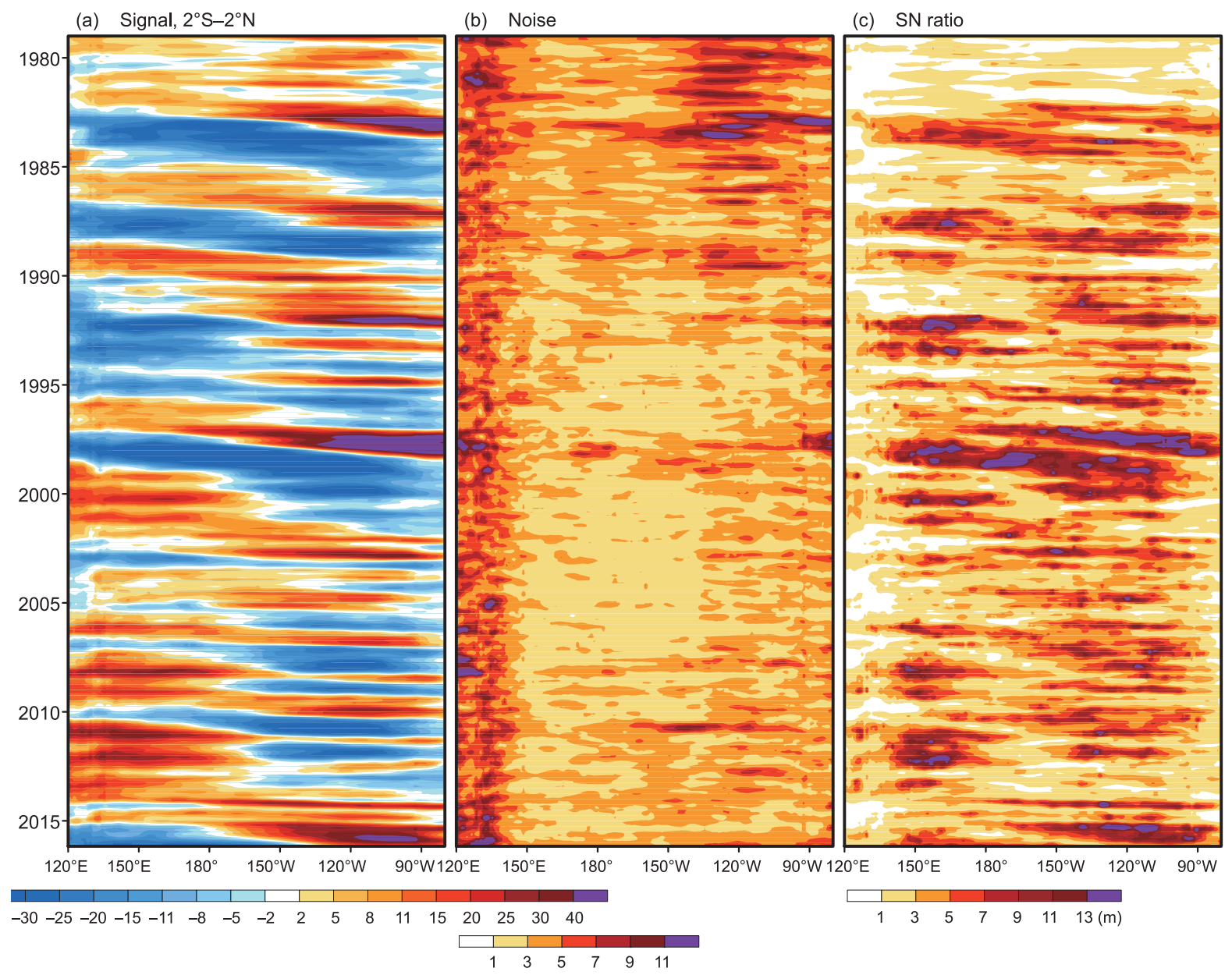

Figure 2 Longitude-time plot of (a) ensemble mean, (b) ensemble spread, and (c) absolute value of ensemble mean divided by ensemble spread of D20 anomaly $(\mathrm{m})$ averaged over the $2^{\circ} \mathrm{S}-2^{\circ} \mathrm{N}$ band in the equatorial Pacific. The quantities shown are 3-month-running mean. 
where $X_{k}(t)$ denotes an individual ORA and $N$ is the total number of ORAs. The uncertainty in the ensemble mean estimate is quantified by the ensemble spread (ES) among ocean reanalyses

$$
E S(t)=\sqrt{\frac{1}{N-1} \sum_{k=1}^{N}\left(X_{k}(t)-E M(t)\right)^{2}} .
$$

The signal to noise ratio (SNR) is defined as the absolute value of $E M$ divided by $E S$, and tells us how robust the signal is relative to uncertainty among the analyses.

An ensemble of six operational ORAs that start from 1979 and are updated in real-time were used in the ensemble approach. Table 1 provides a summary of the six ORAs included in the study. The six ORAs were used to calculate the signal, noise and signal to noise ratio of subsurface temperature anomalies from 1979 to present.

Because the anomaly in the depth of $20^{\circ} \mathrm{C}$ isotherm (D20) is well correlated with ocean heat content variability that provides the ocean memory for long-term predictability of ENSO (Zebiak, 1989), we examined D20 anomaly in the equatorial Pacific from 1979 to present (Figure 2). The ensemble mean of D20 anomaly, referred to as the signal, clearly shows that the 2015/16 El Niño is among the three strongest El Niños since 1979. The maximum D20 anomaly in the 2015/16 El Niño reached about $40 \mathrm{~m}$ in the far eastern Pacific, however, was weaker than that in the 1982/83 and 1997/98 El Niño (Figure 2a). The SNR for the 1982/83 El Niño was smaller than that for the 1997/98 and 2015/16 El Niño (Figure 2c). This is because in situ observations were very sparse before the completion of the TAO array in 1994, and consequently the uncertainty among the analyses was larger. With the availability of the TAO array and satellite altimetry data since 1993, the ensemble spread, referred to as the noise, reduced from about $5-7 \mathrm{~m}$ to $1-3 \mathrm{~m}$ in early $1990 \mathrm{~s}$ (Figure $2 \mathrm{~b}$ ). It is also interesting to note that the ensemble spread increased slightly after early 2000 s. This may be partially related to climatology biases induced by uncertainties of ORAs in the 1980s and early 1990s when observations were sparse and partially related to the advent of Argo data in the early 2000s, and how different ORAs might handle the data differently.

We also examined the intraseasonal variability in the evolution of the 2015/16 El Niño using the pentad D20 anomaly from the GODAS. The monthly D20 anomaly derived from the ensemble mean of six ORAs was used to compare the evolution of the 2015/16 El Niño with that of the 1982/83 and 1997/98 El Niño.

\subsection{Sea surface temperature and other variables}

For sea surface temperature (SST), we used the weekly Optimal Interpolation SST version 2 (OISST; Reynolds et al., 2002). The weekly OISST is a satellite-based analysis that uses in situ data for bias adjustments of the Advanced Very High Resolution Radiometer (AVHRR) data with one degree resolution, and is available starting November 1981. We also used the pentad wind data from the NCEP/NACR reanalysis (Kalnay et al., 1996), and the pentad outgoing longwave radiation (OLR) produced by NOAA as a proxy for deep convection. Anomalies for all variables were calculated for the 1981-2010 base period.

\section{Results}

\subsection{Characteristics in the evolution of the $2015 / 2016 \mathrm{El}$ Niño}

The 2015/16 El Niño developed from a background of weak El Niño conditions in late 2014. The 2014 El Niño, widely anticipated by the operational and research community in spring

Table 1 List of ocean reanalysis products used in the study ${ }^{\text {a) }}$

\begin{tabular}{|c|c|c|c|c|c|}
\hline Product & Forcing & Ocean model & $\begin{array}{l}\text { Data assimilation } \\
\text { method }\end{array}$ & Ocean observations & Analysis period \\
\hline $\begin{array}{c}\text { NCEP } \\
\text { (GODAS) }\end{array}$ & NCEP-R2 & $1^{\circ} \times 1 / 3^{\circ}$ MOM3 & 3DVAR & $\mathrm{T} / \mathrm{SST}$ & $\begin{array}{l}\text { 1979-present } \\
\text { Behringer and Xue, } 2004\end{array}$ \\
\hline $\begin{array}{c}\text { GFDL } \\
(\mathrm{ECDA})\end{array}$ & Coupled DA & $1^{\circ} \times 1 / 3^{\circ} \mathrm{MOM} 4$ & EnKF & $\mathrm{T} / \mathrm{S} / \mathrm{SST}$ & $\begin{array}{c}\text { 1979-present } \\
\text { Zhang et al., } 2007\end{array}$ \\
\hline $\begin{array}{c}\text { BOM } \\
(\text { PEODAS })\end{array}$ & $\begin{array}{l}\text { ERA40 to } 2002 ; \\
\text { NCEP-R2 thereafter }\end{array}$ & $\begin{array}{c}1^{\circ} \times 2^{\circ} \\
\mathrm{MOM} 2\end{array}$ & EnKF & $\mathrm{T} / \mathrm{S} / \mathrm{SST}$ & $\begin{array}{l}\text { 1970-present } \\
\text { Yin et al., } 2011\end{array}$ \\
\hline $\begin{array}{l}\text { ECMWF } \\
\text { (ORAS4) }\end{array}$ & $\begin{array}{l}\text { ERA40 to } 1988 ; \text { ERAi } \\
\text { thereafter }\end{array}$ & $1^{\circ} \times 1 / 3^{\circ} \mathrm{NEMO} 3$ & 3DVAR & $\mathrm{SLA} / \mathrm{T} / \mathrm{S} / \mathrm{SST} / \mathrm{SIC}$ & $\begin{array}{l}\text { 1979-present } \\
\text { Balmaseda et al., } 2013\end{array}$ \\
\hline $\begin{array}{c}\text { JMA } \\
\text { (MOVE-G2) }\end{array}$ & $\begin{array}{l}\text { JRA55 corr }+ \\
\text { CORE Bulk }\end{array}$ & $1^{\circ} \times 0.5^{\circ}$ MRI.COM3 & 3DVAR & $\mathrm{SLA} / \mathrm{T} / \mathrm{S} / \mathrm{SST} / \mathrm{SIC}$ & $\begin{array}{l}\text { 1979-present } \\
\text { Toyoda et al., } 2013\end{array}$ \\
\hline $\begin{array}{c}\text { NASA } \\
\text { (MERRA Ocean) }\end{array}$ & $\begin{array}{l}\text { MERRA + } \\
\text { Bulk }\end{array}$ & $0.5^{\circ} \times 1 / 4^{\circ} \mathrm{MOM} 4$ & EnOI & SLA/T/S/SST/SIC & $\begin{array}{l}\text { 1979-present } \\
\text { Vernieres et al., } 2012\end{array}$ \\
\hline
\end{tabular}

a) The data assimilation column lists the observation types used for their estimation (T/S for temperature and salinity; SLA: altimeter-derived sea level anomalies; SST: sea surface temperature, SIC: sea-ice concentration), as well as assimilation techniques used for reanalysis: Ensemble Optimal Interpolation (EnOI), Ensemble Kalman Filter (EnKF), Variational methods (3DVar). The atmospheric surface forcing is usually provided by atmospheric reanalyses, using either direct daily fluxes, or different bulk formulations. There are also systems that use fluxes from coupled data assimilation systems (Coupled DA). 
2014, did not materialize (McPhaden, 2015). The reason for the stalled El Niño has been partially attributed to the exceptionally strong easterly wind burst in summer 2014 that was unfavorable for El Niño development (Hu and Fedorov, 2016) and the inability of models to capture the cold SST anomaly (SSTA) in the southeastern Pacific (Zhu et al., 2016).

Westerly wind bursts (WWBs) are widely believed to play a critical role in the initiation and intensification of El Niño (e.g. Fedorov et al., 2015; Chen et al., 2015). Three WWB episodes were observed in January-March 2015 over water warmer than $29^{\circ} \mathrm{C}$ (Figure 3a). Each of the westerly wind episodes had a zonal fetch that progressively extended slightly further eastward. The zonal fetch of the last westerly episode in mid-March 2015 extended to near the dateline, which was effective in pushing down the thermocline in the central-eastern Pacific to be $24 \mathrm{~m}$ deeper than average (Figure 4c). The WWB episodes are often associated with the Madden-Julian Oscillation (MJO), a wave in the atmosphere with a period of 30-60 days. Further, deep atmospheric convection and low-level westerly winds are often associated with the MJO. In 2015, deep atmospheric convection, characterized by OLR less than 240 , was closely associated with the westerly wind events, and deep convection was apparent over waters warmer than $29^{\circ} \mathrm{C}$ (Figure 3c). Ocean currents forced by the westerly wind events advected warm water eastward near the equator and played a critical role in the evolution of the ENSO cycle (Picaut et al., 1996). The eastern edge of the warm pool, represented by the $29^{\circ} \mathrm{C}$ water, moved eastward significantly during March-May 2015 (Figure 3b), and partly may be due to advection of the warm pool water forced by the two westerly episodes in March and May 2015.

One salient feature about the 2015/16 El Niño was a large number of westerly episodes. Three more westerly episodes were observed in late June, mid-October 2015 and January 2016, and the last episode had the largest zonal fetch, extending to west of the dateline (near $150^{\circ} \mathrm{W}$ ). Deep convection was clearly associated with those westerly episodes. The east edge of the deep convection followed the $29^{\circ} \mathrm{C}$ water well, and extended to near $135^{\circ} \mathrm{W}$ around January 2016 (Figure 3c). However, the SST near the dateline cooled down rapidly after the westerly episode in January 2016 and the $29^{\circ} \mathrm{C}$ water retreated quickly westward at the same time (Figure 3b). The rapid cooling of SST in the western and central Pacific since mid-January 2016 was apparently associated with the return of easterly trade winds in the region, which seems initiate the

$2^{\circ} \mathrm{S}-2^{\circ} \mathrm{N}$ average, 3 pentad running mean

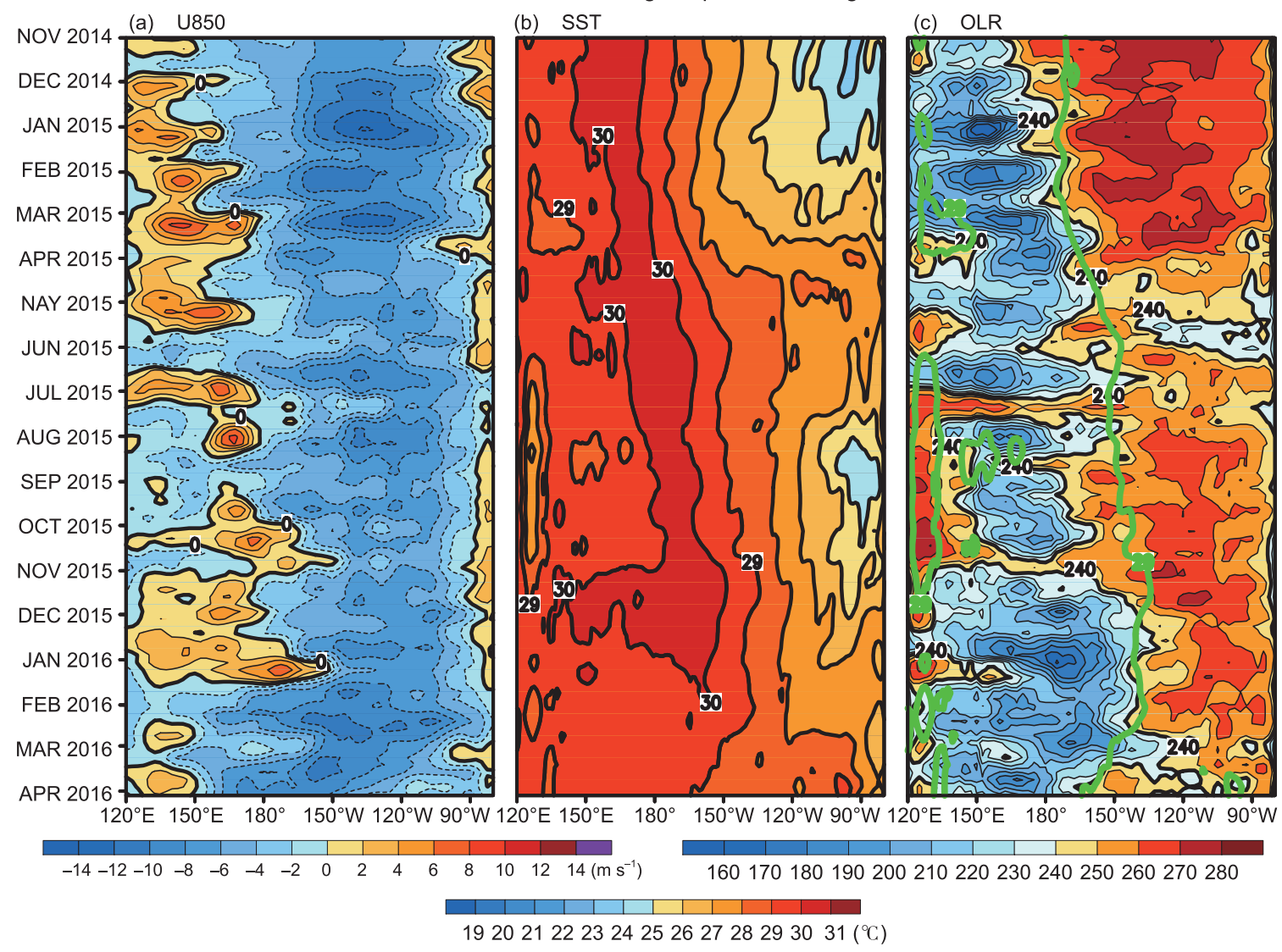

Figure 3 Longitude-time plot of (a) zonal wind at $850 \mathrm{mb}$ (u850), (b) sea surface temperature (SST) averaged in $2^{\circ} \mathrm{S}-2^{\circ} \mathrm{N}$, and (c) outgoing longwave radiation $(\mathrm{OLR})$ averaged in $5^{\circ} \mathrm{S}-5^{\circ} \mathrm{N}$ in the equatorial Pacific. The quantities shown are 3-pentad-running mean. The green line in (c) shows the position of $29^{\circ} \mathrm{C}$ water. 


\section{$2^{\circ} \mathrm{S}-2^{\circ} \mathrm{N}$ Average, 3 Pentad Running Mean}

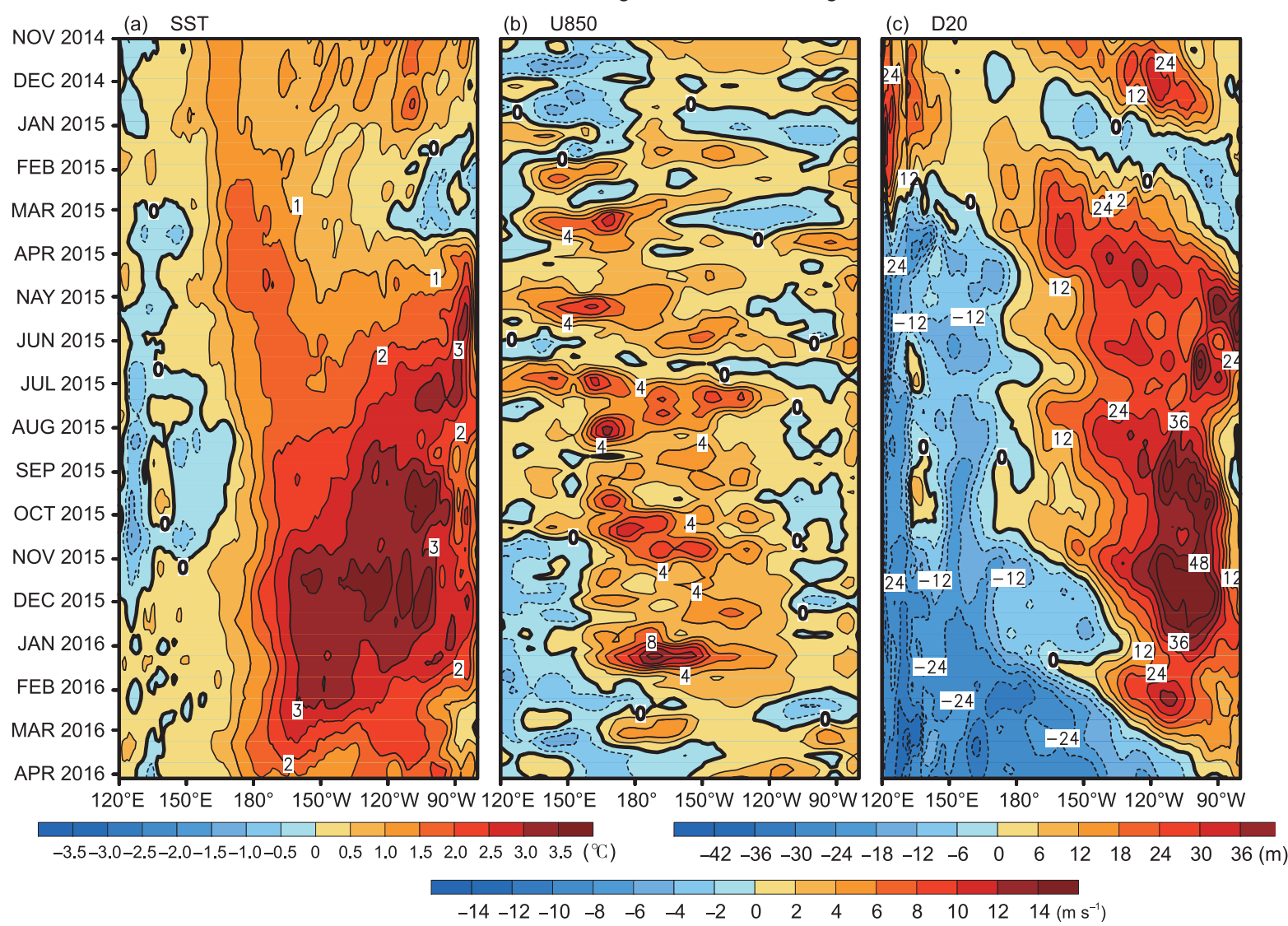

Figure 4 Longitude-time plot of (a) SST anomaly, (b) zonal wind anomaly at $850 \mathrm{mb}$ (u850), and (c) depth of $20^{\circ} \mathrm{C}$ anomaly (D20) averaged in $2^{\circ} \mathrm{S}-2^{\circ} \mathrm{N}$ in the equatorial Pacific. The quantities shown are 3 pentad-running mean.

decay phase of the El Niño.

To understand the mechanism for the development and decay of the 2015/16 El Niño, it is important to examine the evolution of subsurface temperature anomalies since they provide the ocean heat content conditions for both initiation and decay of El Niño through the recharge and discharge paradigm for ENSO (Jin, 1997). The anomaly in D20 represents the temperature anomaly near the thermocline that has the largest influences on SST anomaly in the central-eastern Pacific through the vertical advection of temperature anomaly by the mean upwelling. Westerly Wind Anomalies (WWAs) in February-March 2015 forced a strong downwelling oceanic Kelvin wave (DWKV) that deepened the D20 by $30 \mathrm{~m}$ and this positive D20 anomaly propagated from near the dateline to the west coast of South America in 2 months (Figure 4c). A positive SSTA emerged in the far eastern Pacific in April 2015 partly forced by the local WWAs and partly due to the influences of DWKV (Figure 4). At the same time, an eastward zonal current anomaly (see http://www.oscar.noaa.gov), forced by the WWAs, advected warm water eastward, and increased the positive SSTA at the eastern edge of the warm pool.

Three more DWKVs followed, forced by the westerly episodes in May, July and October 2015. The four DWKVs contributed to the low frequency component of D20 variability that was persistently negative (positive) west (east) of the dateline during April-November 2015. The maximum D20 anomaly reached about $48 \mathrm{~m}$ and was located east of $120^{\circ} \mathrm{W}$ in November-December 2015. However, this anomaly was much weaker than that of the 1997/98 El Niño (90 m, McPhaden, 1999). This is because the WWAs were much weaker during the 2015/16 El Niño than during the $1997 / 98$ El Niño (we will compare the wind anomaly in the next section).

An upwelling oceanic Kelvin wave (UWKV) emerged in early November, coincident with the development of easterly wind anomalies west of $160^{\circ} \mathrm{E}$. The emergence of easterly wind anomalies in the far western Pacific are often associated with the decay phase of El Niño since they favor UWKVs (Weisberg and Wang, 1997). Although the UWKV was stalled by another DWKV forced by the strong westerly episode in January 2016, a following UWKV succeeded in eliminating all positive D20 anomalies by the end of March 2016. By April 2016, positive subsurface temperature anomalies were confined to the upper $20 \mathrm{~m}$ between $180^{\circ}-130^{\circ} \mathrm{W}$, and strong negative temperature anomalies occupied most of the equatorial Pacific. With initialization of the strong negative ocean heat content anomaly in the western and eastern 
Pacific, the majority of models suggested La Niña-conditions will likely emerge by fall 2016 (http://iri.columbia.edu/ourexpertise/climate/forecasts/enso/current).

\subsection{Historical perspectives since 1979}

We next evaluate the 2015/16 El Niño in a historical perspective since 1979. During the mature phase of El Nino, convection typically enhances and trade winds weaken near the dateline in response to the SST warming in the central-eastern Pacific. To see the relationship, the average SSTA in the NINO4 $\left(150^{\circ}-90^{\circ} \mathrm{W}, 5^{\circ} \mathrm{S}-5^{\circ} \mathrm{N}\right)$ and $\mathrm{NINO} 3\left(160^{\circ} \mathrm{E}-150^{\circ} \mathrm{W}, 5^{\circ} \mathrm{S}-5^{\circ} \mathrm{N}\right)$ region was compared with the average $850 \mathrm{mb}$ zonal wind anomaly and OLR anomaly in the two regions separately (Figure 5).

One of the most outstanding features of the 2015/16 El Niño was that NINO4 reached a historical high about $1.7^{\circ} \mathrm{C}$ in late 2015 (Figure 5a). As expected, the average zonal wind anomaly was highly correlated with the average SSTA in the NINO4 region. However, the amplitude of WWAs reached about $4-8 \mathrm{~m} / \mathrm{s}$ during the mature phase of El Niños before 1999 , but it reached only about $1-2 \mathrm{~m} / \mathrm{s}$ during the El Niños after 1999. During the 2015/16 El Niño, the amplitude of WWAs reached about $4 \mathrm{~m} / \mathrm{s}$, about $1 / 2$ of that during the 1982/83 and 1997/98 El Niño.

Another unique feature of the 2015/16 El Niño was that the
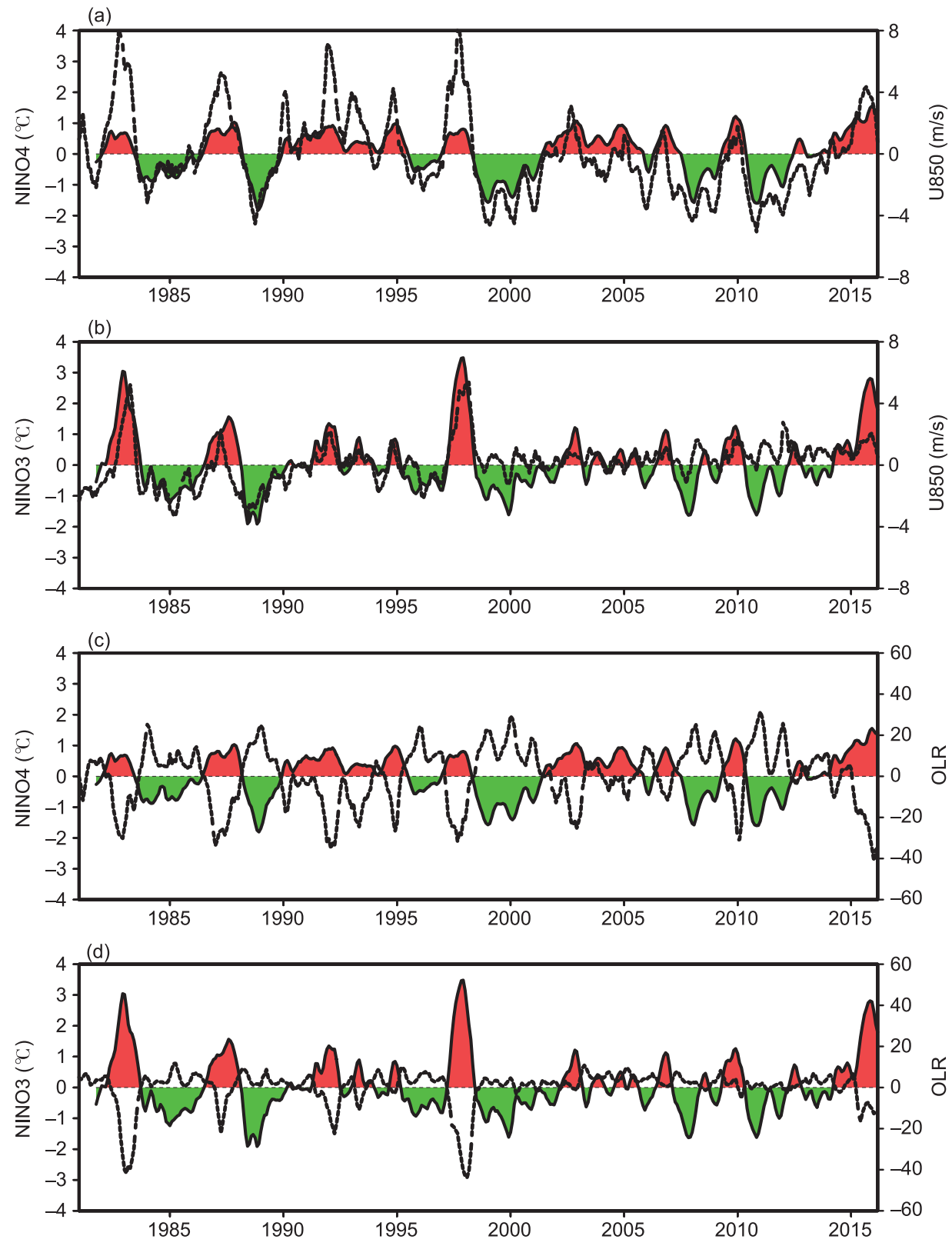

Figure 5 Average $850 \mathrm{mb}$ zonal wind (black dash line) and SST anomaly (shading) in the (a) NINO4 and (b) NINO3 region. (c), (d) are the same as (a), (b) except for OLR (black dash line) and SST (shading) anomaly. The quantities shown are 3 month-running mean. 
NINO3 reached about $3^{\circ} \mathrm{C}$, comparable to that in the $1982 / 83$ and 1997/98 El Niño (Figure 5b). The amplitude of WWAs in the NINO3 region was weaker than that in the NINO4 region except during the 1982/83 and 1997/98 El Niño. After 1999, the amplitude of the zonal wind anomaly in the NINO3 region was persistently weak. During the 2015/16 El Niño, the amplitude of WWAs increased, but it was only about $1 / 4$ of that during the 1982/82 and 1997/98 El Niño.

During the 2015/16 El Niño, the amplitude of negative OLR anomalies averaged in the NINO4 region, a measure of deep convection, also reached a historical high since 1979 (Figure 5c). The exceptionally strong convection increased freshwater fluxes into the ocean and decreased sea surface salinity substantially (Gasparin and Roemmich, 2016; also see the real-time Blended Analysis of Surface Salinity (BASS) product by Xie et al. (2014) featured in the CPC's Monthly Ocean Briefing PPTs). Considering the fact that freshwater flux forcing and sea surface salinity variability can affect the ocean through the barrier layer (Lukas and Lindstrom, 1991; Vialard and Delecluse, 1998), and may induce a positive feedback effect on ENSO through the stratification stability in the upper ocean (Zheng and Zhang, 2012), it is possible that the exceptionally strong precipitation over the NINO4 region was closely associated with the historical warming in the NINO4 region through interactions involving freshwater flux, the barrier layer, vertical entrainment, and SST in the region. In the NINO3 region, on the other hand, the enhanced convection during the $2015 / 16$ El Niño was only $1 / 4$ of that during the $1982 / 83$ and $1997 / 98$ El Niño (Figure 5d). We will further compare the OLR anomalies during the three strong El Niño events in the next section.

Another interesting feature is that the 2015/16 El Niño emerged in an epoch dominated by weak NINO3 variability since 2000 (NINO3 variability was strong before 2000, Figure $5 b$ ). The decadal change of NINO3 variability is associated with the change of El Niños from dominant eastern-Pacific warming before 1999 to frequent central-Pacific warming after 1999 (Lee and McPhaden, 2010; Kumar and $\mathrm{Hu}, 2014)$. The change of ENSO characteristics was also related to the enhancement of trade winds since the 1990s, which caused a shallower thermocline and cooler SST in the eastern Pacific in the 2000s (Amaya et al., 2015). The sudden increase in amplitude of NINO3 during the 2015/16 El Niño seems to indicate a regime shift to a more strong NINO3 variability in the future, but this remains to be seen.

The D20 anomaly averaged in the equatorial belt measures how much warm water is accumulated in the equatorial $\mathrm{Pa}-$ cific, which is referred to as Warm Water Volume (WWV) by Meinen and McPhaden (2000). WWV is particularly useful predictor of ENSO events with a 6-9 month lead time (Zebiak, 1989; Xue et al., 2000). The D20 anomaly averaged in the western Pacific $\left(120^{\circ} \mathrm{E}-155^{\circ} \mathrm{W}, 5^{\circ} \mathrm{S}-5^{\circ} \mathrm{N}\right)$ and eastern Pacific $\left(155^{\circ}-80^{\circ} \mathrm{W}, 5^{\circ} \mathrm{S}-5^{\circ} \mathrm{N}\right)$ are useful in monitoring the east-west dipole structure of D20 anomaly during the mature phase of ENSO events.

Figure 6 shows that WWV generally leads NINO3.4 by 6-9 months for ENSO events before 2000, but the lead time became much shorter after 2000 (McPhaden, 2012). WWV clearly led the weak warming in 2014, but was more in phase with the warming of NINO3.4 in 2015. Another feature of WWV is that it usually decreases rapidly, a discharge of ocean heat content, during the mature phase of El Niño. For the strong discharge cases, La Niña conditions usually follow in the next year. Indeed, moderate negative WWV emerged by March 2016, indicating a likelihood for transition to La Niña in late 2016.

The western pole of the D20 anomalies is generally out of phase with NINO3.4 SST. It also shows a decadal shift to warmer conditions since 2000, when negative D20 anomalies associated with the central-Pacific warming events (the 2002, 2004, 2006 and 2009 El Niño) were very weak. However, for the 2015/16 El Niño, the western pole of D20 anomaly decreased rapidly since November 2015 (Figure 6b), and reached a negative value that was similar to those of the El Niños before 2000 .

The eastern pole of the D20 anomalies is highly correlated with NINO3.4, and there is a good correspondence between the amplitude of D20 and SST anomalies in that region. During the mature phase of the 2015/16 El Niño, the amplitude of the western and eastern pole of D20 anomalies was comparable to that during the $1982 / 83$ event but weaker than that during the 1997/98 El Niño. We will compare the characteristics in the evolution of the D20 anomalies during the three strong El Niños next.

\subsection{Comparison with the $1982 / 83$ and $1997 / 98$ El Niños}

The seasonal evolution of the 2015/16 El Niño was compared with that of the 1997/98 El Niño in Figures 7-8. During the January-February-March (JFM) season of the El Niño year, both El Niños had a positive (negative) D20 anomaly near the equator (along $8^{\circ}-10^{\circ} \mathrm{N}$ ) and positive SSTA in the western-central Pacific. By April-May-June (AMJ), positive SSTA stretched from the dateline to the west coast of South America, and the north-south dipole of D20 anomaly enhanced and negative D20 anomaly appeared in the far western Pacific. Associated with the positive SSTA were westerly wind anomalies and enhanced convection near the dateline. One noticeable difference was that there was a second warming center near Baja California in 2015, but not in 1997. Probably related to the second warming center, the enhanced convection in the eastern Pacific centered further northward in 2015 than in 1997. By July-August-September (JAS), the second warming center expanded to near the dateline, which seemed to cause westerly wind anomalies to be centered north of the equator. The westerly wind anomaly on the equator 

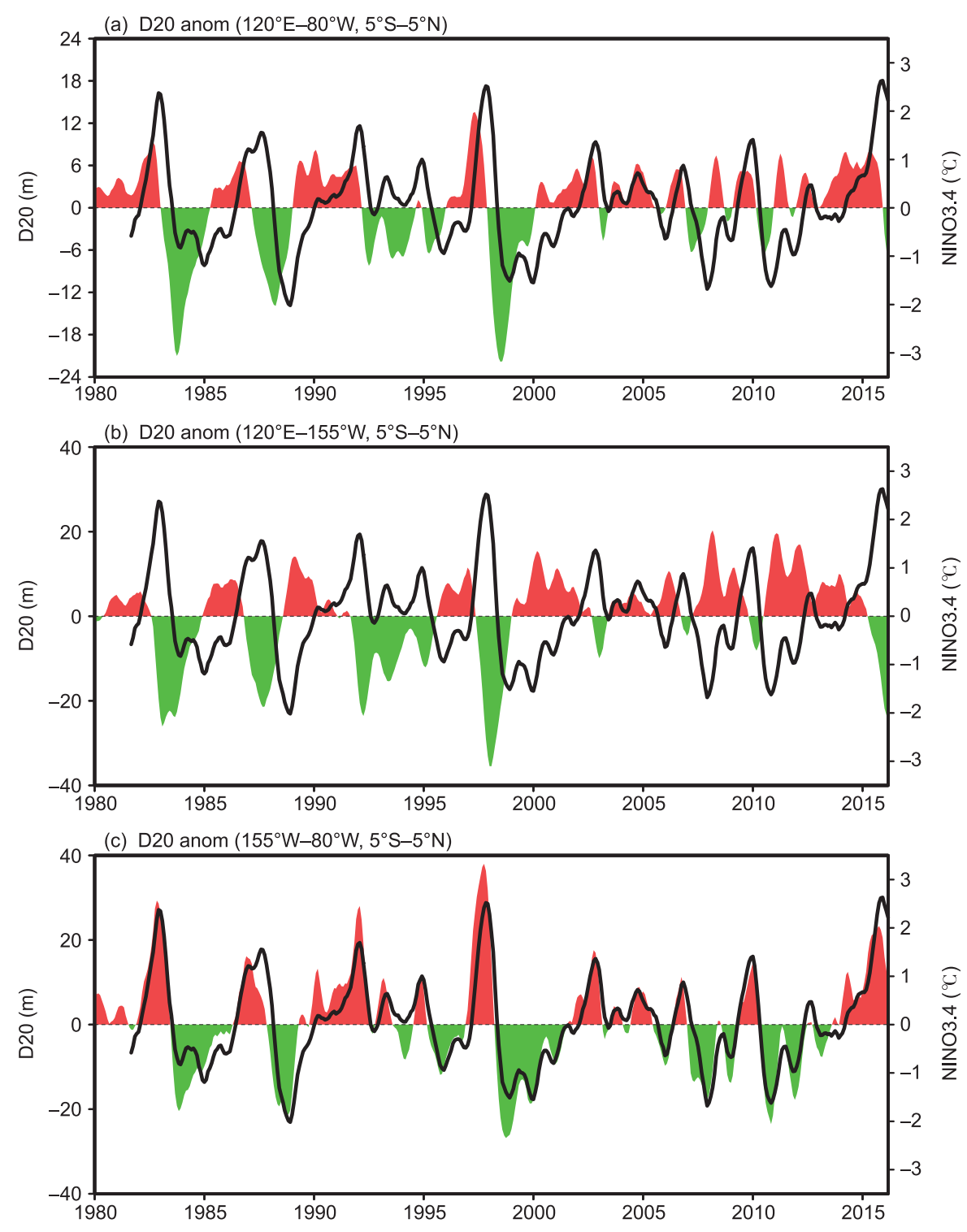

Figure 6 NINO3.4 SST (black line) is overlaid with D20 anomaly (shading) for average in (a) $\left(120^{\circ} \mathrm{E}-80^{\circ} \mathrm{W}, 5^{\circ} \mathrm{S}-5^{\circ} \mathrm{N}\right),(\mathrm{b})\left(120^{\circ} \mathrm{E}-155^{\circ} \mathrm{W}, 5^{\circ} \mathrm{S}-5^{\circ} \mathrm{N}\right)$, and (c) $\left(155^{\circ}-80^{\circ} \mathrm{W}, 5^{\circ} \mathrm{S}-5^{\circ} \mathrm{N}\right)$. The quantities shown are 3 month-running mean.

in 2015 was much weaker than that in 1997. Consistently, the warming in the eastern Pacific and the dipole of the D20 anomaly were weaker as well.

In terms of NINO3.4, the 2015/16 El Niño peaked in November 2015, while the 1997/98 El Niño peaked in January 1998, two months later in the calendar year. For October-November-December (OND), the SSTA was comparable in the central Pacific, but much weaker in the eastern Pacific in 2015 than in 1997. The westerly wind anomaly, D20 anomaly, and OLR anomaly were all significantly weaker in 2015 than in 1997. By January-February-March (JFM) of the following El Niño year, the negative D20 anomaly in the western-central Pacific in 1998 was twice as strong as that in 2016. In addition, enhanced convection extended all the way to the west coast of South America in winter $1997 / 98$, while it was confined to west of $120^{\circ} \mathrm{W}$ in winter 2015/16. Another noticeable difference was that in the northeastern Pacific the positive D20 anomaly was confined to near the coast in summer/fall 1997, but not in 2015.

To understand the factors that contributed to the differences between the evolution of the 2015/16 and 1997/98 El Niño, the differences of seasonal anomalies are shown in Figure 9. Compared to the $1997 / 98$ El Niño, SST near the dateline was about $0.5-1{ }^{\circ} \mathrm{C}$ warmer in all seasons in the evolution of the 2015/16 El Niño. In addition, SST was warmer (colder) north (south) of the equator throughout of 2015, compared to 1997. The SST differences enhanced the zonal SST gradient along the equator, consistent with the easterly wind differences that blow from cold to warm SST differences. Interestingly, the persistent easterly wind differences between $170^{\circ} \mathrm{E}-160^{\circ} \mathrm{W}$ resembled the enhanced trade winds since 2000 (Wen et al., 

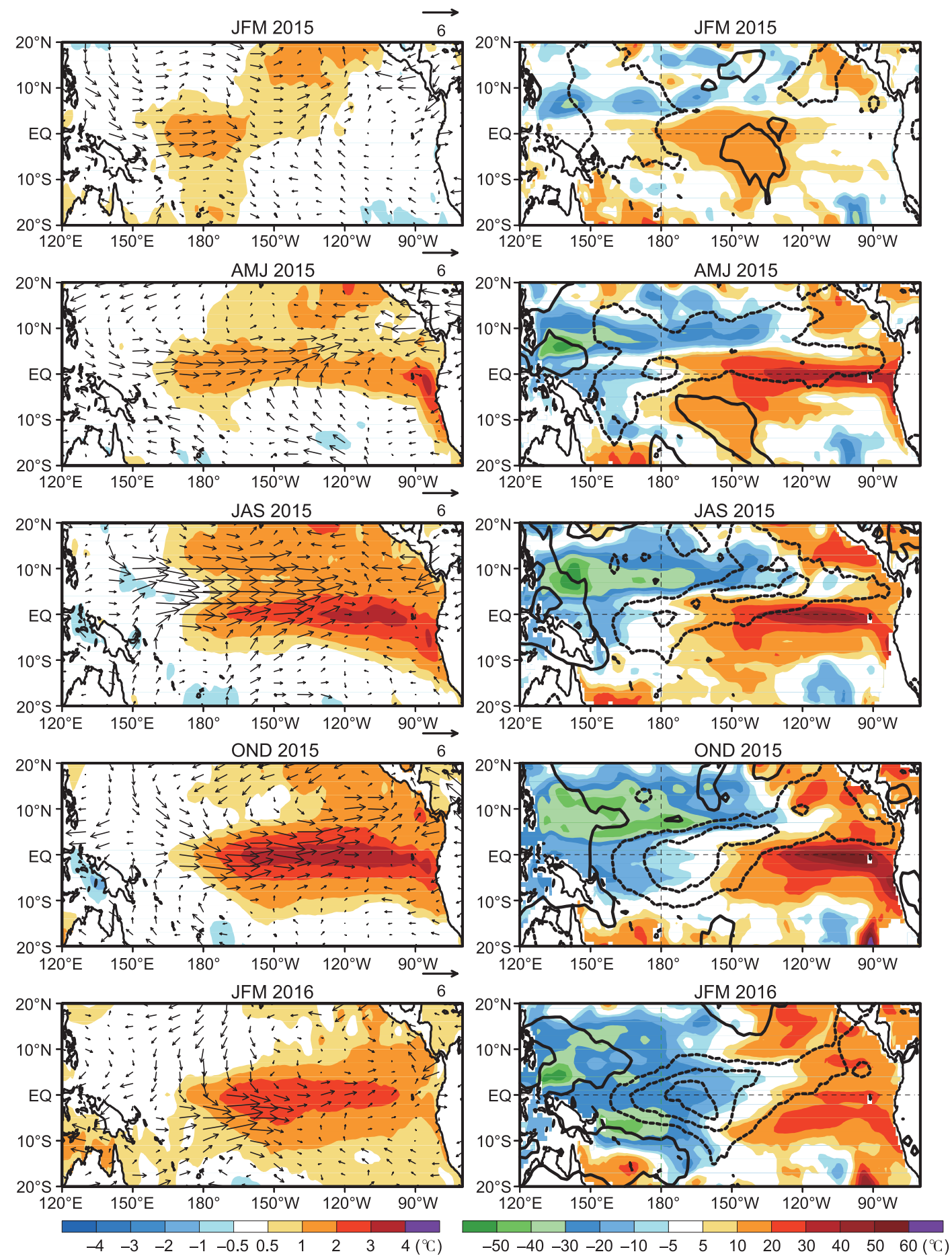

Figure 7 From the top to bottom, seasonal mean anomaly for January-February-March (JFM), April-May-June (AMJ), July-August-September (JAS), October-November-December (OND) of 2015 and JFM 2016. (left panel) SST anomaly ( ${ }^{\circ} \mathrm{C}$, shading) overlaid with anomalous $850 \mathrm{mb}$ wind vector (m/s, see label on the top right of each plot), (right panel) D20 anomaly ( $\mathrm{m}$, shading) overlaid with OLR anomaly (dash contours are for $-70,-50,-30-10$, and solid contours for $10,30,50,70)$.

(2014) and the linear trend in surface zonal winds during 1990-2009 (Amaya et al., 2015). It seems that the persistent easterly wind differences between the evolutions of the two El Niños were partially related to the enhanced trade wind since 2000, which has contributed to reduced warming in the eastern Pacific in 2015, compared to 1997. In addition, the El
Niño precursors, the westerly wind anomalies in the western Pacific and equatorial heat content build-up in early spring, were also weaker in 2015 than in 1997, which were less favorable for development of an extremely strong El Niño in 2015 than in 1997.

The differences in D20 and OLR anomalies were consistent 

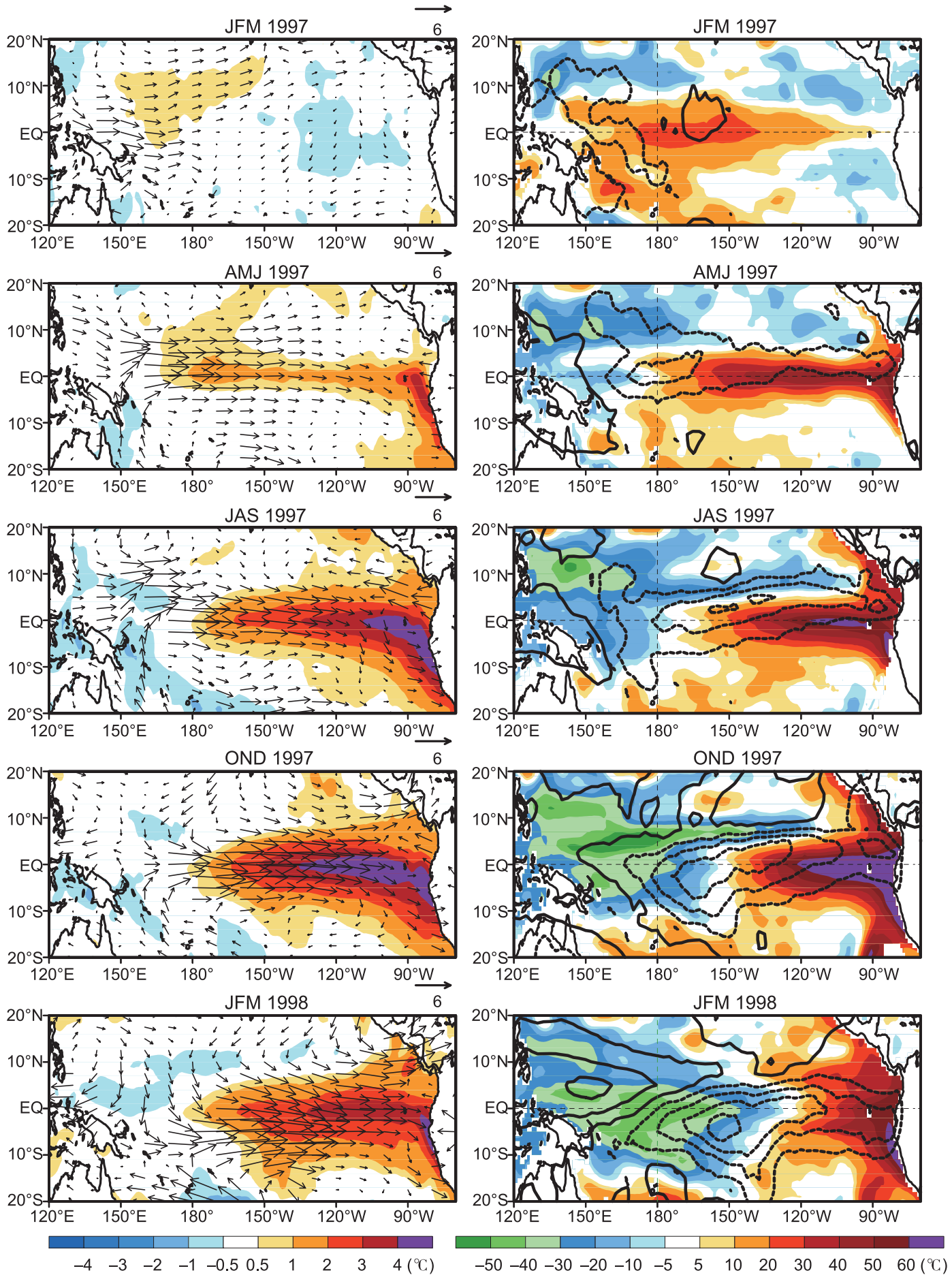

Figure 8 From the top to bottom, seasonal mean anomaly for January-February-March (JFM), April-May-June (AMJ), July-August-September (JAS), October-November-December (OND) of 1997 and JFM 1998. (left panel) SST anomaly $\left({ }^{\circ} \mathrm{C}\right.$, shading) overlaid with anomalous $850 \mathrm{mb}$ wind vector (m/s, see label on the top right of each plot), (right panel) D20 anomaly (m, shading) overlaid with OLR anomaly (dash contours are for $-70,-50,-30-10$, and solid contours for $10,30,50,70)$

with the differences in SST and zonal wind anomalies, except the differences in D20 and OLR anomalies were largest during the winter and early spring of the following year. We note that the D20 was about $40 \mathrm{~m}$ shallower near the west coast of South America in the winter of 2015/16 than 1997/98. Those differences would lead to significant differences in El Niño impacts over this region (Takahashi et al., 2014).

The seasonal evolution of the 2015/16 El Niño was also similar to that of the 1982/83 El Niño except the onset of SSTA was about 2-3 months earlier in 2015 than in 1982 

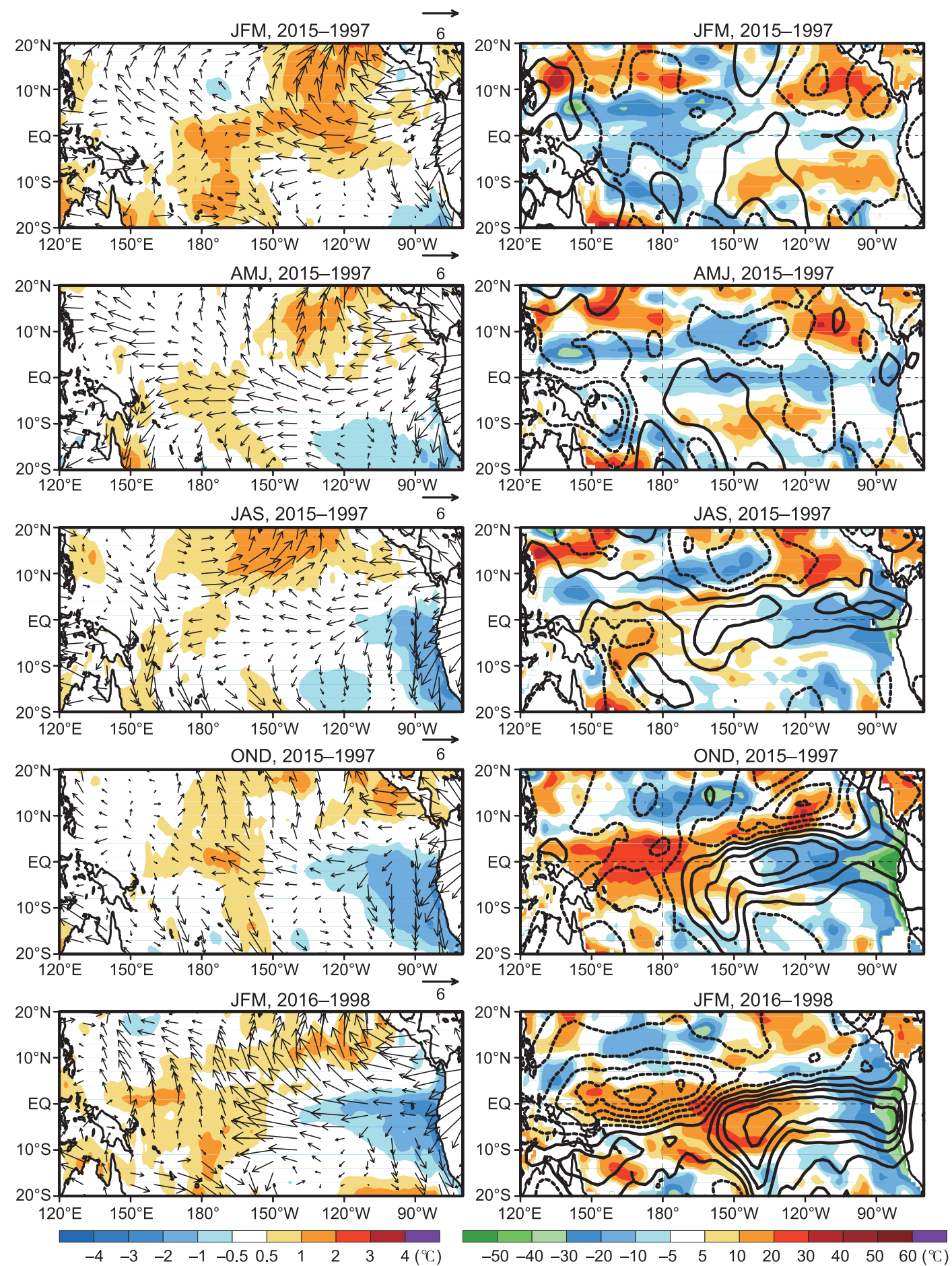

Figure 9 From the top to bottom, seasonal mean anomaly for January-February-March (JFM), April-May-June (AMJ), July-August-September (JAS), October-November-December (OND) of the difference between the 2015/16 and 1997/98 El Niño. (left panel) SST anomaly $\left({ }^{\circ} \mathrm{C}\right.$, shading) overlaid with anomalous $850 \mathrm{mb}$ wind vector (m/s, see label on the top right of each plot), (right panel) D20 anomaly (m, shading) overlaid with OLR anomaly (dash contours are for $-70,-50,-30-10$, and solid contours for $10,30,50,70)$.

(Figure 10). However, the positive SSTA grew rapidly during fall, and reached even stronger amplitude in the eastern Pacific by winter 1982/83 than in winter 2015/16. The westerly wind anomaly, D20 anomaly, and OLR anomaly were all stronger at the peak phase of 1982/83 than 2015/16 El Niño.
The differences of seasonal anomalies between the evolution of the 2015/16 and 1982/83 El Niño were somewhat similar to those between the 2015/16 and 1997/98 (Figure 11). Similarities include warm SST near the dateline and easterly wind differences in the central and eastern Pacific. The per- 

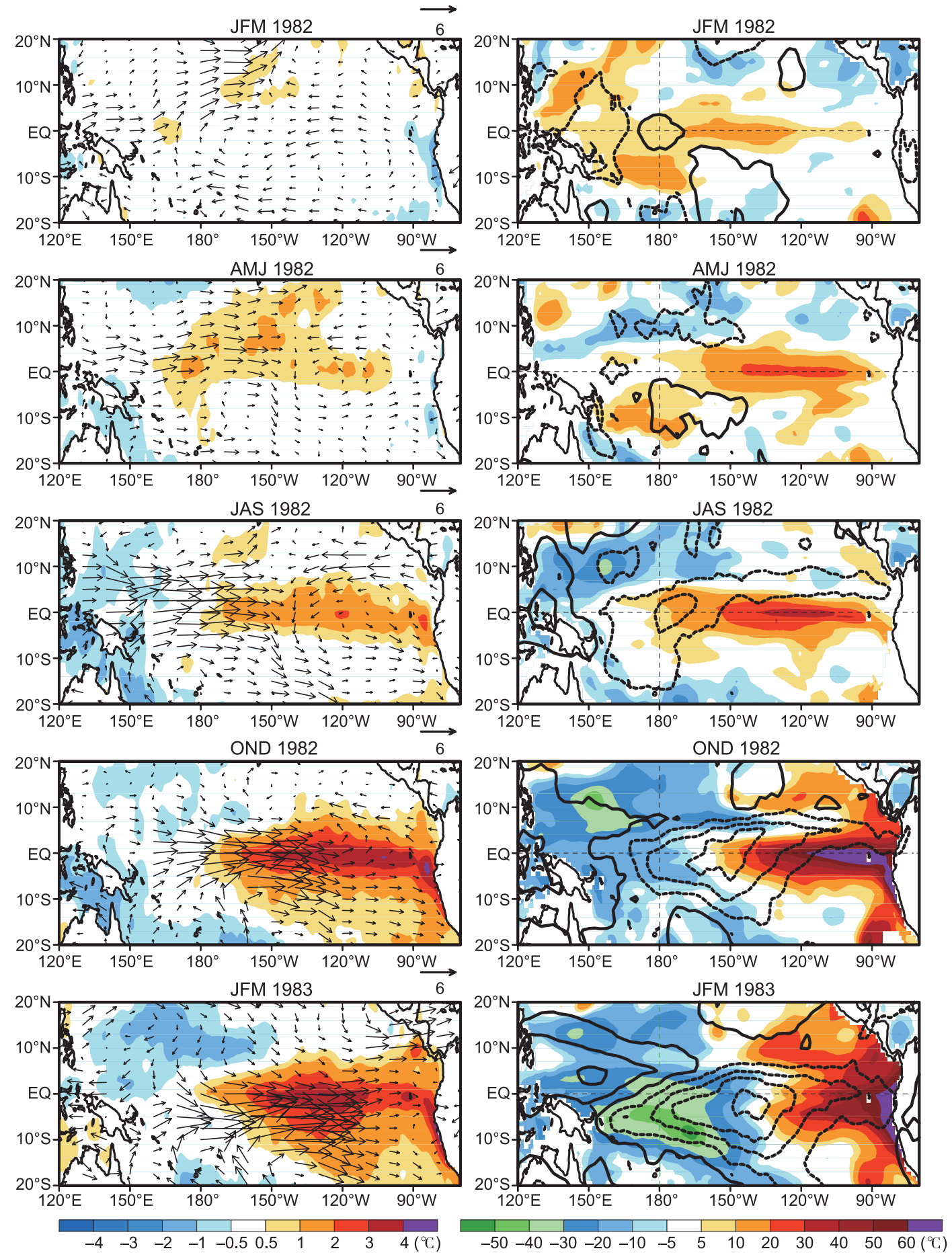

Figure 10 From the top to bottom, seasonal mean anomaly for January-February-March (JFM), April-May-June (AMJ), July-August-September (JAS), October-November-December (OND) of 1982/83 El Niño. (left panel) SST anomaly $\left({ }^{\circ} \mathrm{C}\right.$, shading) overlaid with anomalous $850 \mathrm{mb}$ wind vector (m/s, see label on the top right of each plot), (right panel) D20 anomaly ( $\mathrm{m}$, shading) overlaid with OLR anomaly (dash contours are for $-70,-50,-30-10$, and solid contours for $10,30,50,70)$.

sistent easterly wind differences probably limited the warming in the far eastern Pacific in 2015 compared to in 1982. Similarly, the D20 was about $40 \mathrm{~m}$ shallower near the west coast of South America, and the OLR anomaly was significantly weaker in the central-eastern Pacific in the winter of $2015 / 16$ than $1982 / 83$.

\section{Discussion and summary}

The 2015/16 El Niño developed from a background of weak El Niño conditions in late 2014 (NINO3.4 was around $0.8^{\circ} \mathrm{C}$ ), and NINO3.4 reached around $3^{\circ} \mathrm{C}$ in November 2015, which was comparable to that in the $1997 / 98 \mathrm{El}$ Niño considering 

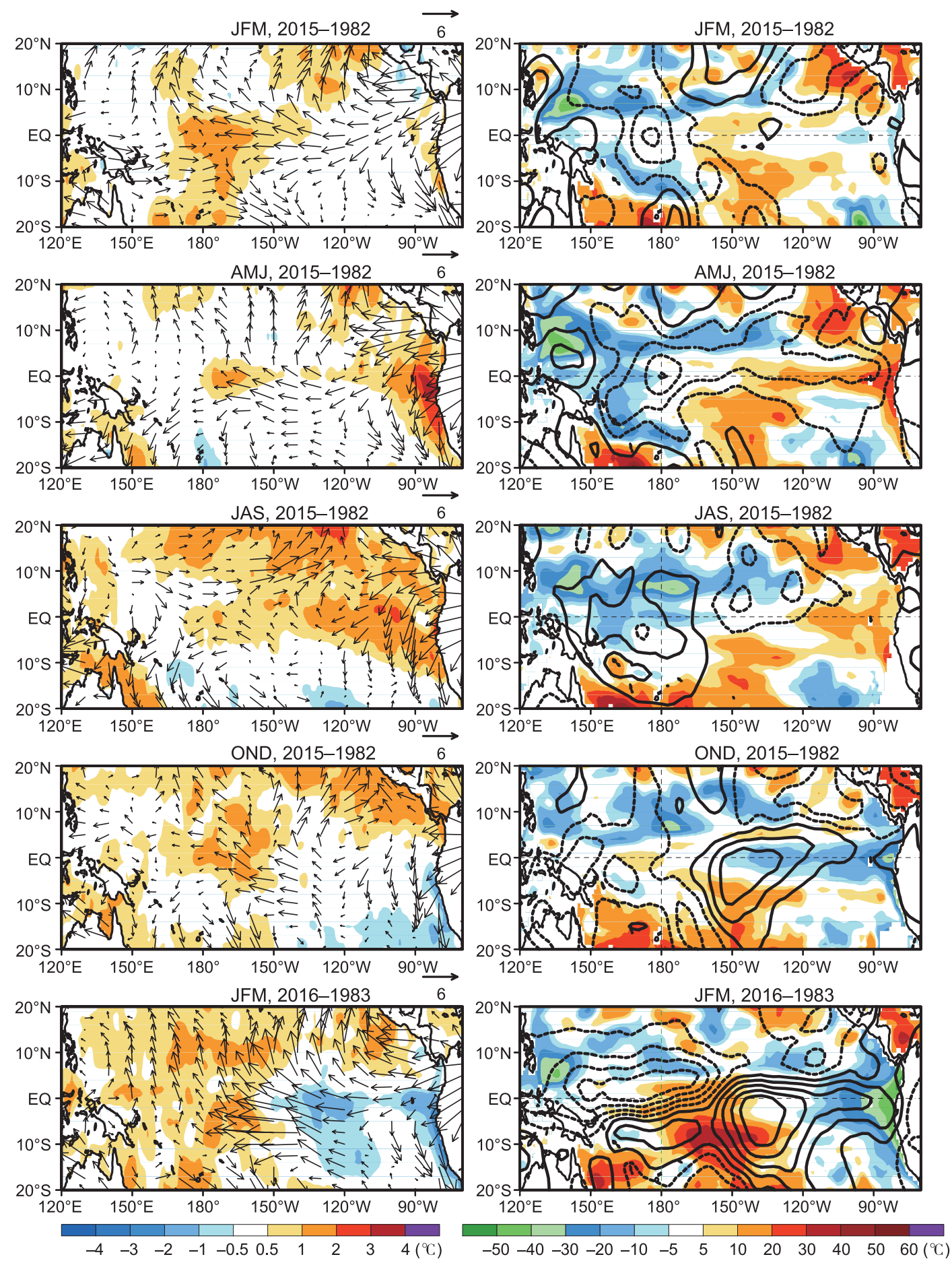

Figure 11 From the top to bottom, seasonal mean anomaly for January-February-March (JFM), April-May-June (AMJ), July-August-September (JAS), October-November-December (OND) of the difference between the 2015/16 and 1982/83 El Niño. (left panel) SST anomaly $\left({ }^{\circ} \mathrm{C}\right.$, shading) overlaid with anomalous $850 \mathrm{mb}$ wind vector $(\mathrm{m} / \mathrm{s}$, see label on the top right of each plot), (right panel) D20 anomaly (m, shading) overlaid with OLR anomaly (dash contours are for $-70,-50,-30-10$, and solid contours for $10,30,50,70)$.

there are uncertainties in the NINO3.4 index (Huang et al., 2016). We described the major characteristics in the evolution of the 2015/16 El Niño using various data sets that include the weekly OI SST product, surface winds from the NCEP/NCAR reanalysis, OLR and subsurface temperature analysis from an ensemble operational ocean reanalyses and place it in the context of historical ENSO events since 1979.

One salient feature about the 2015/16 El Niño was a large number of westerly wind burst (WWBs) episodes throughout the 2015. Three WWB episodes were observed in January-March 2015. The zonal fetch of the last westerly episode in mid-March 2015 extended to near the dateline, 
and was effective in exciting a downwelling Kelvin wave (DWKV) that deepened the thermocline by more than $30 \mathrm{~m}$ and contributed to the development of positive SST anomalies in the far eastern Pacific in April. Another DWKV, forced by a westerly episode in May 2015, further deepened the thermocline and raised positive SST anomaly in the central-eastern Pacific. Forced by the two WWBs, an eastward zonal current anomaly advected the warm pool water eastward, leading to an eastward propagation of positive SSTA in the western-central Pacific. Two more DWKVs followed, forced by the westerly episodes in July and October 2015. The maximum D20 anomaly reached about $48 \mathrm{~m}$ east of $120^{\circ} \mathrm{W}$ in November-December 2015, which was much weaker than that of the 1997/98 El Niño (90 m according to McPhaden, 1999).

An UWKV emerged in early November 2015, and was associated with the development of easterly wind anomalies east of $160^{\circ} \mathrm{E}$. Although the UWKV was stalled temporally by another DWKV forced by the strong westerly episode in January 2016, the following UWKV propagated negative D20 anomaly to the far eastern Pacific by the end of March 2016. By April 23, 2016, positive subsurface temperature anomalies were confined in the upper $20 \mathrm{~m}$ between $180^{\circ}-130^{\circ} \mathrm{W}$, and strong negative temperature anomalies occupied most of the equatorial Pacific, indicating a likelihood for a transition to La Niña-conditions by fall 2016.

The most salient feature about the 2015/16 El Niño was a large number of WWBs. Chen et al. (2016) suggest that the first burst of westerly winds in early March was mainly induced by the Arctic Oscillation (AO) event, and the westerly wind burst in May was induced by anomalous southerly winds from the Australian continent. Many studies suggest that the frequency of WWBs depends on the state of ENSO and the state-dependent WWBs during the El Nino growth phase during spring/summer play an important role in determining the eventual strength of the El Nino event (Fedorov et al., 2015; Chen et al., 2016; Levine et al., 2016). However, since the strength of El Niño is not uniquely defined, which depend on variables (e.g. SST, OLR, winds and D20 anomalies) and regions used in quantification as illustrated in the paper, the roles of WWBs on the development and eventual strength of El Niño need to be further studied.

Another outstanding features of the 2015/16 El Niño was that NINO4 reached a historical high about $1.7^{\circ} \mathrm{C}$ in late 2015 , which was about $0.8^{\circ} \mathrm{C}\left(1^{\circ} \mathrm{C}\right)$ higher than the $1997 / 98$ and $1982 / 83$ El Niño. NINO3.4 reached about $3^{\circ} \mathrm{C}$, an amplitude comparable to that in the 1982/83 and 1997/98 El Niño, but NINO3 and NINO1+2 were weaker than the other two strong El Niño events. However, the amplitude of the westerly wind anomaly during the 2015/16 was only $1 / 2(1 / 4)$ of that of the 1982/83 and 1997/98 El Niños in the NINO4 (NINO3) region. The differences in seasonal mean wind anomaly between the 2015/16 and the other two El Niños feature persis- tent easterly wind differences between $170^{\circ} \mathrm{W}-120^{\circ} \mathrm{W}$, which seems linked to the enhanced trade wind regime since 2000. So the easterly wind differences probably contributed to the weaker warming in NINO3 and NINO1+2 in the 2015/16 El Niño than that in the $1997 / 98$ and 1982/83 El Niños. Consistently, enhanced convection in 2015 was displaced 20 degree westward, and the maximum D20 anomaly was about $1 / 3$ to 1/2 of that in 1997 and 1982 near the west coast of South America.

It should be noted that differences in the atmospheric responses to various flavors of ENSO (in that a maximum in SST anomalies in the eastern and central parts of the equatorial Pacific) may excite different atmospheric teleconnection patterns. Therefore, the amplitude of NINO3.4 SST alone should not be taken as a sole indicator of the spatial pattern and the strength of atmospheric and oceanic responses. In fact, the impacts on subsurface temperature anomalies of the California Current System during the 2015/16 El Niño were much weaker than during the 1982/83 and 1997/98 El Niño (Jacox et al., 2016). This highlights the need for more holistic measures of ENSO events and/or regional metrics of their effects.

The cause for the extremely high NINO4 during the 2015/16 El Niño is unclear. The warming could be partially related to the persistent positive phase of the Pacific Decadal Oscillation (PDO) following summer 2014 (http://www.cpc.ncep.noaa.gov/products/GODAS/ocean_briefing.shtml), which favors central Pacific warming, as well as the long-term warming trend due to the anthropogenic forcings. In addition, the "stalled" $2014 \mathrm{El}$ Niño pre-conditioned NINO4 to be $1^{\circ} \mathrm{C}$ above-normal before the onset of the 2015/16 El Niño. During the spring and summer 2015, frequent WWBs helped to push the warm pool water eastward, enhancing the warming near the dateline. In addition, during the 2015/16 El Niño, the amplitude of negative OLR anomalies averaged in the NINO4 region, a measure of deep convection, also reached a historical high since 1979. The exceptionally strong precipitation over the NINO4 region reduced sea surface salinity and increased the barrier layer thickness (Gasparin and Roemmich, 2016), which could warm the surface by reducing the vertical entrainment cooling.

Interannual variability of sea surface salinity is believed to play an active role in the development and growth of ENSO events through its influences on the barrier layer thickness, vertical entrainment mixing, surface layer momentum budget and horizontal pressure gradient (Vialard and Delecluse, 1998; Zheng and Zhang, 2012). Cravatte et al. (2009) suggests that the western Pacific Warm Pool has significantly freshened and there has been an eastward extension of the SSS fronts near the equator and under the South Pacific Convergence Zone since 1955. As a result, there is an increase in the equatorial barrier layer thickness that would probably en- 
hance the impacts of westerly wind burst events on the development of El Niño. However, the quality of salinity analysis in the operational ORAs is generally poor (Shi et al., 2015). Improvements in salinity analysis in operational ORAs are necessary, so that we can adequately monitor and understand the impacts of both temperature and salinity variability during the evolution of ENSO events in the future.

Acknowledgements We would like to thank Dr. Dake Chen for the invitation and suggestion for the paper. We also thank Dr. Caihong Wen and $D r$. Emily Becker for their constructive comments and suggestions at the internal review. The scientific results and conclusions, as well as any view or opinions expressed herein, are those of the author(s) and do not necessarily reflect the views of NWS, NOAA, or the Department of Commerce.

\section{References}

Ando K, Matsumoto T, Nagahama T, Ueki I, Takatsuki Y, Kuroda Y. 2005. Drift characteristics of a moored conductivity-temperature-depth sensor and correction of salinity data. J Atmos Ocean Technol, 22: 282-291

Amaya D J, Xie S P, Miller A J, McPhaden M J. 2015. Seasonality of tropical Pacific decadal trends associated with the 21 st century global warming hiatus. J Geophys Res Oceans, 120: 6782-6798

Balmaseda M A, Mogensen K, Weaver A T. 2013. Evaluation of the ECMWF ocean reanalysis system ORAS4. Q J R Meteorol Soc, 131: $1132-1161$

Balmaseda M A, Co-authors. 2015. The ocean reanalyses intercomparison project (ORA-IP). J Oper Oceanogr, 7: 81-99

Behringer D W, Ji M, Leetmaa A. 1998. An improved coupled model for ENSO prediction and implications for ocean initialization. Part I: The ocean data assimilation system. Mon Weather Rev, 126: 1013-1021

Behringer D W, Xue Y. 2004. Evaluation of the global ocean data assimilation system at NCEP: The Pacific Ocean. In: Eighth Symposium on Integrated Observing and Assimilation System for Atmosphere, Ocean, and Land Surface, AMS 84th Annual Meeting, Washington State Convention and Trade Center. Seattle. 11-15

Cravatte S, Delcroix T, Zhang D, McPhaden M, Leloup J. 2009. Observed freshening and warming of the western Pacific Warm Pool. Clim Dyn, 33: 565-589

Chen D, Lian T, Fu C, Cane M A, Tang Y, Murtugudde R, Song X, Wu Q, Zhou L. 2015. Strong influence of westerly wind bursts on El Niño diversity. Nat Geosci, 8: 339-345

Chen S, Wu R, Chen W, Yu B, Cao X. 2016. Genesis of westerly wind bursts over the equatorial western Pacific during the onset of the strong 2015-2016 El Niño. Atmos Sci Lett, 17: 384-391

Fedorov A V, Hu S, Lengaigne M, Guilyardi E. 2015. The impact of westerly wind bursts and ocean initial state on the development, and diversity of El Niño events. Clim Dyn, 44: 1381-1401

Gasparin F, Roemmich D. 2016. The strong freshwater anomaly during the onset of the 2015/2016 El Niño. Geophys Res Lett, 43: 6452-6460

Hu S, Fedorov A V. 2016. Exceptionally strong easterly wind burst stalling El Niño of 2014. Proc Natl Acad Sci USA, 113: 2005-2010

Huang B, Xue Y, Zhang D, Kumar A, McPhaden M J. 2010. The NCEP GODAS ocean analysis of the tropical Pacific mixed layer heat budget on seasonal to interannual time scales. J Clim, 23: 4901-4925

Huang B, Thorne P W, Smith T M, Liu W, Lawrimore J, Banzon V F, Zhang H M, Peterson T C, Menne M. 2016. Further exploring and quantifying uncertainties for extended reconstructed sea surface temperature (ERSST) version 4. J Clim, 29: 3119-3142

Jacox M G, Hazen E L, Zaba K D, Rudnick D L, Edwards C A, Moore A M, Bograd S J. 2016. Impacts of the 2015-2016 El Niño on the California current system: Early assessment and comparison to past events. Geophys Res Lett, 43: 7072-7080

Ji M, Behringer D W, Leetmaa A. 1998. An improved coupled model for ENSO prediction and implications for ocean initialization. Part II: The coupled model. Mon Weather Rev, 126: 1022-1034

Jin F F. 1997. An equatorial ocean recharge paradigm for ENSO. Part I: Conceptual model. J Atmos Sci, 54: 811-829

Kalnay E, Kanamitsu M, Kistler R, Collins W, Deaven D, Gandin L, Iredell M, Saha S, White G, Woollen J, Zhu Y, Leetmaa A, Reynolds R, Chelliah M, Ebisuzaki W, Higgins W, Janowiak J, Mo K C, Ropelewski C, Wang J, Jenne R, Joseph D. 1996. The NCEP/NCAR 40-year reanalysis project. Bull Amer Meteorol Soc, 77: 437-471

Kumar A, Hu Z Z. 2014. Interannual and interdecadal variability of ocean temperature along the equatorial Pacific in conjunction with ENSO. Clim Dyn, 42: 1243-1258

Levine A, Jin F F, McPhaden M J. 2016. Extreme noise-extreme El Niño: How state-dependent noise forcing creates El Niño-La Niña asymmetry. J Clim, 29: 5483-5499

Lee T, McPhaden M J. 2010. Increasing intensity of El Niño in the centralequatorial Pacific. Geophys Res Lett, 37: L14603

Lukas R, Lindstrom E. 1991. The mixed layer of the western equatorial Pacific Ocean. J Geophys Res, 96: 3343-3357

McPhaden M J. Ji M, Julian P, Meyers G, Mitchum G T. 1998. The tropical ocean-global atmosphere (TOGA) observing system: A decade of progress. J Geophys Res, 103: 169-14,240

McPhaden M J. 1999. Genesis and evolution of the 1997-98 El Niño. Science, 283: 950-954

McPhaden M J. 2012. A 21st century shift in the relationship between ENSO SST and warm water volume anomalies. Geophys Res Lett, 39: L09706

McPhaden M J. 2015. Playing hide and seek with El Niño. Nat Clim Change, 5: 791-795

Meinen C S, McPhaden M J. 2000. Observations of warm water volume changes in the Equatorial Pacific and their relationship to El Niño and La Niña. J Clim, 13: 3551-3559

Picaut J, Ioualalen M, Menkes C, Delcroix T, McPhaden M J. 1996. Mechanism of the zonal displacements of the Pacific Warm Pool: Implications for ENSO. Science, 274: 1486-1489

Reynolds R W, Rayner N A, Smith T M, Stokes D C, Wang W. 2002. An improved in situ and satellite SST analysis for climate. J Clim, 15: 1609-1625

Shi L, Alves O, Wedd R, Balmaseda M A, Chang Y, Chepurin G, Ferry N, Fujii Y, Gaillard F, Good S A, Guinehut S, Haines K, Hernandez F, Lee T, Palmer M, Peterson K A, Masuda S, Storto A, Toyoda T, Valdivieso M, Vernieres G, Wang X, Yin Y. 2015. An assessment of upper ocean salinity content from the ocean reanalyses inter-comparison project (ORAIP). Clim Dyn, doi: 10.1007/s00382-015-2868-7

Stockdale T N, Anderson D L T, Balmaseda M A, Doblas-Reyes F, Ferranti L, Mogensen K, Palmer T N, Molteni F, Vitart F. 2011. ECMWF seasonal forecast system 3 and its prediction of sea surface temperature. Clim Dyn, 37: 455-471

Takahashi K, Martinez R, Montecinos A, Dewitte B, Gutiérrez D, RodriguezRubio E. 2014. Regional applications of observations in the eastern Pacific. In: Report of the Tropical Pacific Observing System 2020 Workshop (TPOS 2020). Vol II. Scripps Institution of Oceanography, GCOS184/GOOS-206/WCRP-6/2014. San Diego: United States Publication. 171-205

Toyoda T, Fujii Y, Yasuda T, Usui N, Iwao T, Kuragano T, Kamachi M. 2013. Improved analysis of the seasonal-interannual fields by a global ocean data assimilation system. Theoret Appl Mech Jpn, 61: 31-48

Trenberth K E, Branstator G W, Karoly D, Kumar A, Lau N C, Ropelewski C. 1998. Progress during TOGA in understanding and modeling global teleconnections associated with tropical sea surface temperatures. J Geophys Res, 103: 14291-14324

Vernieres G, Keppenne C, Rienecker M M, Jacob J, Kovach R. 2012. The 
GEOS-ODAS, description and evaluation. NASA Tech. Rep. Series on Global Modeling and Data Assimilation, NASA/TM-2012-104606, Vol. 30

Vialard J, Delecluse P. 1998. An OGCM study for the TOGA decade. Part II: Barrier-layer formation and variability. J Phys Oceanogr, 28: 1089-1106 Weisberg R H, Wang C. 1997. A Western Pacific oscillator paradigm for the El Niño-Southern Oscillation. Geophys Res Lett, 24: 779-782

Wen C, Kumar A, Xue Y, McPhaden M J. 2014. Changes in tropical Pacific thermocline depth and their relationship to ENSO after 1999. J Clim, 27: 7230-7249

Xie P, Boyer T, Bayler E, Xue Y, Byrne D, Reagan J, Locarnini R, Sun F, Joyce R, Kumar A. 2014. An in situ-satellite blended analysis of global sea surface salinity. J Geophys Res Oceans, 119: 6140-6160

Xue Y, Leetmaa A, Ji M. 2000. ENSO prediction with Markov Models: The impact of sea level. J Clim, 13: 849-871

Xue Y, Huang B, Hu Z Z, Kumar A, Wen C, Behringer D, Nadiga S. 2011.
An assessment of oceanic variability in the NCEP climate forecast system reanalysis. Clim Dyn, 37: 2511-2539

Yin Y, Alves O, Oke P R. 2011. An ensemble ocean data assimilation system for seasonal prediction. Mon Weather Rev, 139: 786-808

Zebiak S E. 1989. Oceanic heat content variability and El Niño cycles. J Phys Oceanogr, 19: 475-486

Zhang S, Harrison M J, Rosati A, Wittenberg A. 2007. System design and evaluation of coupled ensemble data assimilation for global oceanic climate studies. Mon Weather Rev, 135: 3541-3564

Zheng F, Zhang R H. 2012. Effects of interannual salinity variability and freshwater flux forcing on the development of the 2007/08 La Niña event diagnosed from Argo and satellite data. Dyn Atmos Oceans, 57: 45-57

Zhu J, Kumar A, Huang B, Balmaseda M A, Hu Z Z, Marx L, Kinter III J L. 2016. The role of off-equatorial surface temperature anomalies in the 2014 El Niño prediction. Sci Rep, 6: 19677

Open Access This article is distributed under the terms of the Creative Commons Attribution License which permits any use, distribution, and reproduction in any medium, provided the original author(s) and source are credited. 